УДК 612.13.001.575

DOI: 10.17277/voprosy.2015.04.pp.196-201

\title{
DEVELOPMENT OF ONE-DIMENSIONAL MODEL OF ARTERIAL TREE FOR MULTISCALE MODEL OF HEMODYNAMICS FOR RESEARCH OF CEREBRAL CIRCULATION
}

\author{
S. V. Frolov, S. V. Sindeev, D. Liepsch, A. Balasso \\ Tambov State Technical University, Tambov; \\ Munich University of Applied Sciences, Munich (Germany); \\ Technical University of Munich, Munich (Germany) \\ Reviewed by Doctor of Technical Sciences, Professor V. A. Nemtinov
}

Keywords: cardiovascular system; cerebral circulation; hemodynamics; mathematical model.

\begin{abstract}
The arterial tree model, including description of the upper-body arteries and detailed description of cerebral circulation, is proposed. The model can be used for determination of the hemodynamic parameters in the circle of Willis. The simulation results allows for correct definition of the boundary conditions for the multiscale hemodynamic models.
\end{abstract}

For research of the cerebral circulation it is proposed to use a multiscale mathematical model of hemodynamics, consisting of the set of mathematical models of circulation with a different level of detail [1,2].

Mathematical model of the arterial tree is used for coupling of the model of global hemodynamics (0D model) [3] with the model of local hemodynamics of a cerebral artery. In the developed model, the arterial tree is described as set of one-dimensional arteries. The following assumptions are used: blood velocity and pressure changes only in one dimension (along the vessel); blood is modeled as incompressible Newtonian fluid; flow is laminar; vessel wall is isotropic, linear-elastic; vessel wall is incompressible; gravity is neglected. The 1D model structure, including 48 main arteries, is shown in Fig. 1. The model includes upper-body arteries and a detailed description of the cerebral circulation [4].

Фролов Сергей Владимирович - доктор технических наук, профессор, заведующий кафедрой «Биомедицинская техника», e-mail: sergej.frolov@gmail.com; Синдеев Сергей Вячеславович - аспирант кафедры «Биомедицинская техника», ТамбГТУ; Липш Дитер $\mathrm{PhD}$, профессор кафедры механики, Мюнхенский университет прикладных наук, г. Мюнхен (Германия); Балассо Андреа - PhD, профессор, инженер неврологического центра, Технический университет Мюнхена, г. Мюнхен (Германия). 


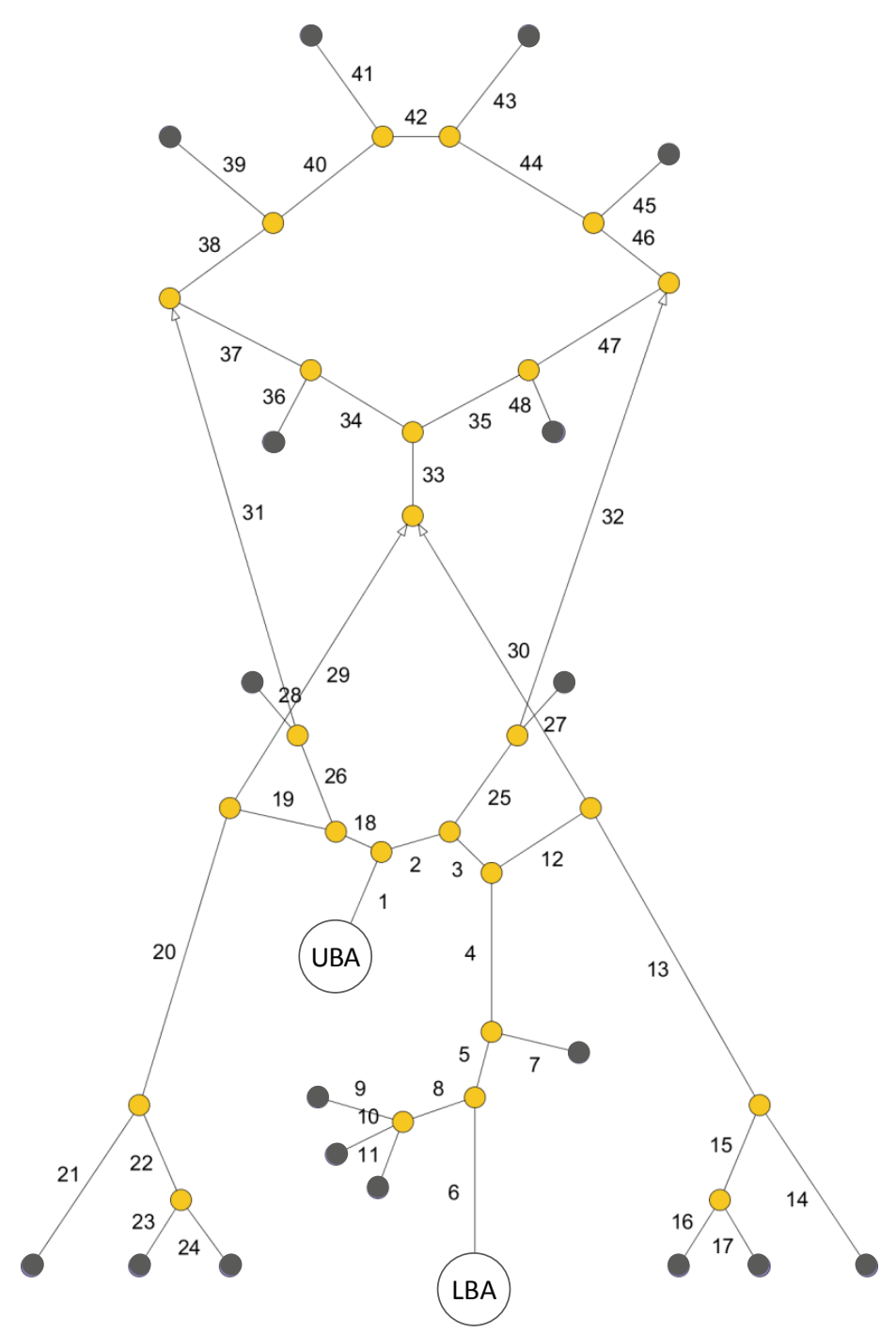

Fig. 1. The structure of the one-dimensional mathematical model of the upper-body and cerebral arteries. Red color is used to represent the nodes of the OD model, yellow color is used for bifurcations; violet color is used for terminal elements

Sample element of the one-dimensional artery is shown in Fig. 2. In one dimensional representation $i$-th vessel with the length $L_{i}$ is divided in $n_{i}$ elementary segments with the length $d x$

$$
n_{i}=\frac{L_{i}}{d x}, \quad i \in[1, N],
$$

where $n_{i}$ is the number of the elementary segments in $i$-th vessel; $L_{i}$ is the length of the $i$-th vessel; $d x$ is the length of the elementary segment of the vessel; $N$ is the total number of arteries in the arterial tree model.

The elementary segment is characterized by the elementary blood volume $d V$ and the pressure $d P$ inside it. The link between $i$-th and $i$-1-th elementary segments is characterized by volumetric blood flow $q_{i-1, i}$. 


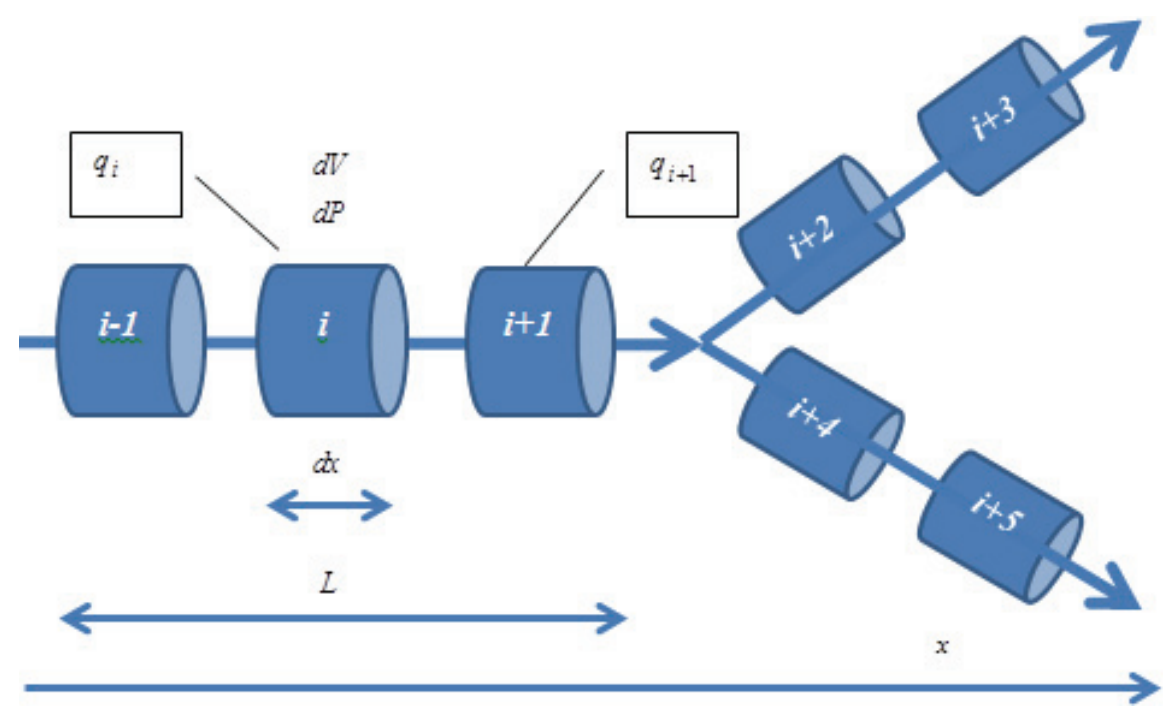

Fig. 2. A schematic representation of the vessel and bifurcation

For the elementary volume $d V_{i}$, it can be written

$$
\frac{d V_{i}}{d t}=\sum_{\text {in }} q_{\text {in } i}-\sum_{\text {out }} q_{\text {out } i},
$$

where $\sum_{\text {in }} q_{\text {in } i}$ is the sum of the volumetric blood flows going in to the $i$-th elementary segment; $\sum_{\text {out }} q_{\text {out } i}$ is the sum of the volumetric blood flows going out the $i$-th elementary segment.

For the pressure $d P_{i}$ in the elementary segment, it can be assumed that the linear dependency between elementary volume $d V_{i}$ and pressure $d P_{i}$

$$
d P_{i}=e_{i}\left(d V_{i}-d U_{i}\right),
$$

where $d U_{i}$ is the unstrained volume of the $i$-th elementary segment; $e_{i}$ is the wall elasticity of the $i$-th elementary segment.

For the volumetric blood flow $q_{i}$, the Poiseuille law can be used:

$$
q_{i}=\frac{\pi d_{i}^{4}}{128 \eta L_{i}} \Delta P_{i},
$$

where $\eta$ is thedynamic viscosity; $d_{i}$ is thediameter of the $i$-th elementary segment.

For the cross-section area, the following assumption is used:

$$
d S_{i}=\pi r_{i}^{2}=\frac{d V_{i}-d U_{i}}{d x}
$$

where $d S_{i}$ is the area of the $i$-th segment cross-section; $r_{i}$ is the radius of the cross-section. 
For the elementary segment, the following equations can be used:

$$
\left\{\begin{array}{l}
\frac{d V_{i}}{d t}=q_{i-1}-q_{i} \\
q_{i}=\frac{P_{i}-P_{i+1}}{R_{i}} ; \\
P_{i}=C_{i}\left(V_{i}-U_{i}\right) .
\end{array}\right.
$$
follows:

After some operations, the final equation for the elementary segment is as

$$
\begin{aligned}
\frac{d V i}{d t} & =\left[\frac{C_{i-1}}{R_{i-1}} V_{i-1}+\frac{\left(-R_{i}-R_{i-1}\right) C_{i}}{R_{i-1} R_{i}} V_{i}+\frac{C_{i+1}}{R_{i}} V_{i+1}\right]+ \\
& +\left[-\frac{C_{i-1} U_{i-1}}{R_{i-1}}+\frac{\left(R_{i}+R_{i-1}\right) C_{i} U_{i}}{R_{i-1} R_{i}}-\frac{C_{i+1} U_{i+1}}{R_{i}}\right]
\end{aligned}
$$

and in the matrix form:

$$
\begin{aligned}
& \frac{d V_{i}}{d t}=\mathbf{A}_{i} \mathbf{V}_{i}+\mathbf{B}_{i} ; \\
& \mathbf{A}_{i}=\left[\begin{array}{lll}
\frac{C_{i-1}}{R_{i-1}} & \frac{\left(-R_{i}-R_{i-1}\right) C_{i}}{R_{i-1} R_{i}} & \frac{C_{i+1}}{R_{i}}
\end{array}\right] ; \\
& \mathbf{V}_{i}=\left[\begin{array}{c}
V_{i-1} \\
V_{i} \\
V_{i+1}
\end{array}\right] ; \\
& \mathbf{B}_{i}=\left[\begin{array}{c}
\frac{-C_{i-1} U_{i-1}}{R_{i-1}}+\frac{\left(R_{i}+R_{i-1}\right) C_{i} U_{i}}{R_{i-1} R_{i}}-\frac{C_{i+1} U_{i+1}}{R_{i}}
\end{array}\right] .
\end{aligned}
$$

Spreading the presented method for the set of elementary segments, the following system can be obtained:

$$
\begin{aligned}
& \frac{d \mathbf{V}}{d t}=\mathbf{A} \mathbf{V}+\mathbf{B} ; \\
& \begin{aligned}
\mathbf{A} & =\left[\begin{array}{ccccc}
\cdots & \ldots & \ldots & \ldots & \ldots \\
\cdots & \ldots & \ldots & \ldots & \ldots \\
\ldots & \frac{C_{i-1}}{R_{i-1}} & \frac{\left(-R_{i}-R_{i-1}\right) C_{i}}{R_{i-1} R_{i}} & \frac{C_{i+1}}{R_{i}} & \ldots \\
\ldots & \ldots & \ldots & \ldots & \ldots \\
\ldots & \ldots & \ldots & \ldots & \ldots
\end{array}\right], \quad \mathbf{V}=\left[\begin{array}{c}
V_{1} \\
V_{2} \\
V_{3} \\
\ldots \\
V_{n}
\end{array}\right] ; \\
\mathbf{B} & =\left[\begin{array}{c}
\ldots \\
\ldots \\
\frac{-C_{i-1} U_{i-1}}{R_{i-1}}+\frac{\left(R_{i}+R_{i-1}\right) C_{i} U_{i}}{R_{i-1} R_{i}}-\frac{C_{i+1} U_{i+1}}{R_{i}} \\
\ldots
\end{array}\right. \\
\ldots &
\end{aligned}
\end{aligned}
$$


In the developed model the unknowns are $q_{i-1}$ and $P_{i+1}$. These values can be obtained from the $0 \mathrm{D}$ model [5]. Thus for the inlet segment where $q_{0}$ is known, the following equation can be used:

$$
\frac{d V_{1}}{d t}=\left[-\frac{C_{1}}{R_{1}} V_{1}+\frac{C_{2}}{R_{1}} V_{2}\right]+\left[\frac{C_{1} U_{1}-C_{2} U_{2}}{R_{1}}+q_{0}\right] .
$$

For the outlet segment of the arterial tree where $P_{n+1}$ is known, the equation will be:

$$
\begin{aligned}
\frac{d V_{n}}{d t} & =\left[\frac{C_{n-1}}{R_{n-1}} V_{n-1}+\frac{\left(-R_{n}-R_{n-1}\right) C_{n}}{R_{n-1} R_{n}} V_{n}\right]+ \\
& +\left[-\frac{C_{n-1} U_{n-1}}{R_{n-1}}+\frac{\left(R_{n}+R_{n-1}\right) C_{n} U_{n}}{R_{n-1} R_{n}}+\frac{P_{n+1}}{R_{n}}\right] .
\end{aligned}
$$

For bifurcations it can be written:

$$
\begin{aligned}
\frac{d V_{i+1}}{d t} & =\left[\frac{C_{i}}{R_{i}} V_{i}-\frac{C_{i+1}}{R_{i}} V_{i+1}+\frac{C_{i+2}}{R_{i+1}} V_{i+2}-\frac{C_{i+4}}{R_{i+1}} V_{i+4}\right]+ \\
& +\left[-\frac{C_{i} U_{i}}{R_{i}}+\frac{C_{i+1} U_{i+1}}{R_{i}}-\frac{C_{i+2} U_{i+2}}{R_{i+1}}+\frac{C_{i+4} U_{i+4}}{R_{i+1}}\right] .
\end{aligned}
$$

Thus, the blood flow in the one-dimensional model can be modeled using equations (1) - (12).

\section{References}

1. Formaggia L., Quarteroni A., Veneziani. Cardiovascular Mathematics. Modeling and simulation of the circulatory system, Series MS\&A, vol. 1, Milan: Springer-Verlag, $2009,528 \mathrm{p}$.

2. Frolov S.V., Sindeev S.V., Lischouk V.A., Gazizova D.Sh., Liepsch D., Balasso A. Voprosy sovremennoi nauki I praktiki. Universitet imeni V.I. Vernadskogo, 2014, vol. 54, no. 4, pp. 86-93.

3. Lishchuk V.A. Matematicheskaya teoriya krovoobrashcheniya (The mathematical theory of circulation), Moscow: Meditsina, 1991, $256 \mathrm{p}$.

4. Frolov S.V., Sindeev S.V., Lischouk V.A., Gazizova D.Sh., Liepsch D., Balasso A. Voprosy sovremennoi nauki I praktiki. Universitet imeni V.I. Vernadskogo, 2013, vol. 48, no. 4, pp. 46-53.

5. Frolov S.V., Sindeev S.V., Lischouk V.A., Gazizova D.Sh. Transactions of the Tambov State Technical University, 2012, vol. 18, no. 3, pp. 546-551.

\section{References}

1. Formaggia, L. Cardiovascular Mathematics. Modeling and Simulation of the Circulatory System / L. Formaggia, A. Quarteroni, A. Veneziani. - Milan : SpringerVerlag, 2009. - 528 p. - (Series MS\&A ; Vol. 1).

2. Modeling Studies of Basilar Artery Blood Flow Given the Global Hemodynamics Factors / S.V. Frolov [et al.] // Вопр. соврем. науки и практики. Университет им. В. И. Вернадского. - 2014. - Vol. 54, No. 4. - Р. 86 - 93. 
3. Лищук, В. А. Математическая теория кровообращения / В. А. Лищук. М. : Медицина, 1991. - 256 с.

4. Development of Multiscale Hemodynamics Model for Research of Basilar Artery Circulation / S. V. Frolov [et al.] // Вопр. соврем. науки и практики. Университет им. В. И. Вернадского. - 2013. - Vol. 48, No. 4. - P. 46 - 53.

5. Hemodynamics Modeling of the Cardiovascular System with a Pulsating Heart / S.V. Frolov [et al.] // Вестн. Тамб. гос. техн. ун-та. - 2012. - Т. 18, № 3. - С. 546 - 551.

\section{Разработка одномерной модели артериального русла с учетом ее использования в многомасштабной модели гемодинамики для исследования церебрального кровообращения}

\section{С. В. Фролов, С. В. Синдеев, Д. Липш, А. Балассо}

ФГБОУ ВПО «Тамбовский государственный технический университет», г. Тамбов;

Мюнхенский университет прикладных наук, г. Мюнхен (Германия); Технический университет Мюнхена, г. Мюнхен (Германия)

Ключевые слова: гемодинамика; математическая модель; мозговое кровообращение; сердечно-сосудистая система.

Аннотация: Предложена модель артериального русла, включающая описание артерий верхней части тела и детальное описание церебрального кровообращения. Данная модель позволяет рассчитать гемодинамические параметры в области круга Виллиса, что может быть использовано для определения граничных условий в многомасштабных моделях гемодинамики.

(C) С. В. Фролов, С. В. Синдеев, Д. Липш, А. Балассо, 2015 